\title{
Complimentary Banquet
}

In Honor of

\section{LUTHER BURBANK}

Given by the

California State Board of Trade at the

PALACE HOTEL

San Francisco

September 14, 1905 


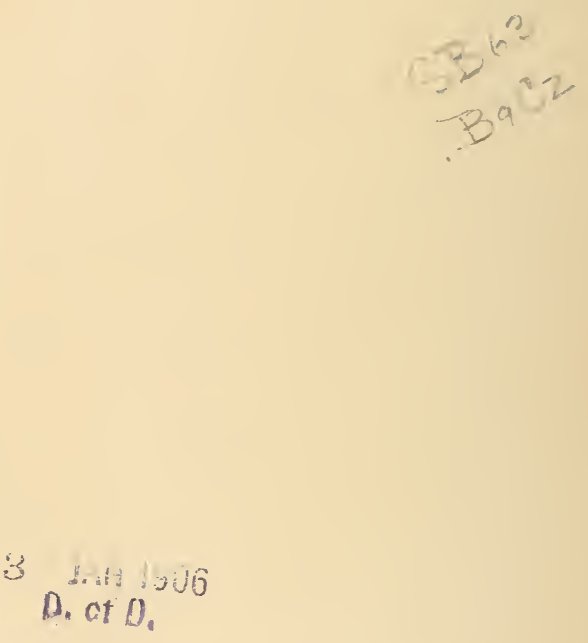






\section{Complimentary Banquet to Luther Burbank}

President N. P. Chipman, on opening, said:

Gentlemen: We are assembled here to-night to honor a man whose whole life from boyhood has been spent in communion with Nature and who has sought with reverent spirit to fathom the laws related to plant life which have been given to us by the God of Nature. It would therefore seem appropriate that before proceeding further we invoke the divine blessing upon the man, upon his work and upon those here assembled. I ask Rabbi Voorsanger to perform this office.

Invocation by Rabbi Voorsanger.

Introductory Remarks of President N. P. Chipman.

I feel much relieved by the arrangement that has devolved upon Mr. Wm. H. Mills the duties of toast-master, and to make the principal address in introducing our distinguished guest. I will, however, be permitted to have your attention for a brief word.

In looking over the names of the men who have come here to lay at the feet of Luther Burbank their tribute of appreciation of the great work he has done, and is still doing, to advance the importance of horticulture, I think I can assure him that they represent the best citizenship of this Commonwealth. I see here present residents of many cities and counties and of many widely separated regions of the State. High officials of all the co-ordinate departments of our State government are here; heads of our chief

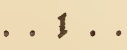




\section{Complimentary Banquet to Luther Burbank}

educational and other institutions; bankers, merchants, business men of many occupations; representatives of the Press, artists, men from all the learned professions, workers in varied industries; horticulturists, gardeners and farmers, whose pursuits have been especially ennobled and widened by his patience and genius-in short, no higher compliment could be paid our guest in the personnel of an assemblage than has been paid him by those who are here to-night to do him honor. They might be more numerous but could not be more truly representative.

And, my friends, there is every reason why this should be so. Many of Mr. Burbank's achievements have become a part of that industry which has made California famous throughout the civilized globe, and that has taken and will ever hold, first place among the agricultural industries of this great State.

When Horace Greeley visited the Santa Clara Valley in 1857 , he stated in one of his letters to the New York Tribune that "fruit growing was destined to become the future glory of California." Mr. Greeley saw with unerring prevision that here were climate and soil in such happy combination, as to give fruit growing a commercial advantage not possessed elsewhere in the United States. Mr. Burbank early in his career discovered that he could here carry on his life work in the open field instead of in the conservatory, and under the protection of artificial heat, in the rigorous climate of New England; and so the State became enriched by his presence and his labors amongst us.

I must not violate the proprieties of the occasion by dealing much with statistics. But there are a few figures it would be well to remember, for they point the rapid evolution of horticulture in California; they also show the

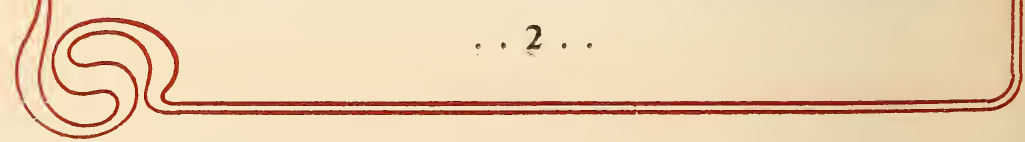




\section{Complimentary Banquet to Luther Burbank}

fulfillment of Mr. Greeley's prophecy, and if they do not entirely account for it, they show the wisdom displayed by Mr. Burbank in having become a Californian.

Prior to the opening of communication by rail with the East the industry had no motive for expansion. So late as in 1880 we exported of fruit but 546 carloads of ten tons each. But in 1890 -ten years later-we sent out 16,194 carloads. In a report which I made to the California State Board of Trade for that year it was shown that the value of the fruit crop, sent out of the State by rail, exceeded that of wheat and flour exports by over half a million dollars.

This was a startling revelation to the wheat growers of the State but the figures could not be disputed. Great activity in tree and vine planting followed and, with greater or less persistency, has been continued, and, to-day, fruit growing is the dominant industry related to the soil.

Sixteen thousand carloads seemed an enormous output, and by many it was thought we had reached the limit of eastern consumption. But mark what has followed. In 1904 our shipments out of the State, by rail and by sea, of the products of the orchards, gardens and vineyards, reached the enormous proportions of over 92,000 carloads of ten tons each. Let me ask you to carry home with you the concrete facts that 76,652 carloads were fruit in various forms; 10,148 carloads were wine and brandy, and 5,251 carloads were vegetables.

You who are engaged in other State industries and have had trouble to procure cars to handle your products, will understand the reason for it. You will understand, too, why the necessity for moving the rapidly developing business of California 


\section{Complimentary Banquet to Luther Burbank}

with her sister states, has inspired the building of a third independent trans-continental railroad to California.

The State Board of Trade was organized in 1886 and has ever since carried forward the work of encouraging immigration and promoting State development. In the earlier period of its work its Hall of Exhibits, of the industrial resources of the State, was visited monthly by a few hundred people from other states. The number of non-residents who now visit the exhibit exceeds 10,000 each month. The correspondence of the Board is as wide as the countries where California is known-and this is almost world-wide. That this organization has proven itself to be one of the chief factors in State development its records show abundant and gratifying proof. Our guest of the night has been for many years an honorary member and when it was suggested that this banquet be extended to him and he was requested to give his consent, and to address his assembled friends, he wrote in reply, among other things: "I accept; but as a speaker not with complacence, pride or satisfaction. But if it is for the benefit of the State Board of the State of California, I submit with as good grace as possible; but depend upon it, my words will be brief, and not to the point."

The State Board has from its inception put forward the fruit growing industry as one of the principal attractions of our State to homeseekers. While not neglecting other industries it has looked upon fruit growing as the principal industry related to the soil which could fully utilize and which would also emphasize to the world the advantages of our unique climate.

No one can now dispute the fact that the tide of immigration to California was set in motion, and has been sustained by the climatic conditions existing here; and these 


\section{Complimentary Banquet to Luther Burbank}

conditions were made know by the marvelous range of fruits grown here-greater in their variety and excellence than can be produced elsewhere in any one country of Europe or in any one or all of the states of the Union.

The orange and lemon have given to Southern California her wonderful prosperity and prestige. The raisin grape has made the Fresno country famous as well as rich. The prune has given to the Santa Clara Valley an enviable reputation on two continents.

These fruits alone have turned the flow of many millions of dollars to the growers of California, that formerly went from this country to Europe; and experience has demonstrated that all the commercial fruits that find a market without the State are grown in all latitudes from Shasta to San Diego.

We have not only captured from foreign competitors the home market for several of our fruit products, but we are successfully invading European countries with our wine and brandy, our prunes, raisins, and dried and canned fruits, and canned vegetables.

Fruit growing like all other industries has been and will continue to be beset by discouragements and vicissitudes. But it has maintained prominence among the tillers of the soil in the countries of Europe for hundreds of years, and it will always have prominence where Nature has furnished conditions favorable to its pursuit. In this respect California stands without a rival.

I offer no apology to our guest, nor to you who are here to welcome him, for this passing mention of the commercial aspect of the fruit growing industry and of its influence in upbuilding the State. While Mr. Burbank has scorned to profit by the many valuable contributions he has made

$$
\text { . } 5 \text {. . }
$$




\section{Complimentary Banquet to Luther Burbank}

to this industry, after all is said of his splendid achievements, they benefit mankind chiefly, as they may be made subservient to the demands of commerce.

It would afford me great pleasure to speak in some detail of Mr. Burbank's unselfish work for the benefit of his fellow man, and of the consecration of his whole soul to that work. I should like to tell you of the many evidences he has given of his intense love for the State of his adoption. But these, and of his high ideals, and of the simple dignity and modesty of his daily life, while the world is applauding in a way to turn the heads of most men, you are to hear from others.

It remains my pleasing duty to transfer to Mr. Mills the important office of further introducing our honored guest and conducting the remaining exercises of the evening.

\section{$\star * *$}

Upon being introduced as toast-master by General N. P. Chipman, Chairman of the evening, Mr. W. H. Mills, in introducing the toast "The health and success of Luther Burbank," said :

Gentlemen: It was a Roman maxim that "Men do most resemble the Gods when they create states." To our modern conception the work of man is most in consonance with the will of the Creator when he augments the life- 
bearing stage of the earth. To make the earth more fruitful and its bloom more radiant has been part of the religious life of the honored guest of the evening.

We will not attempt to recount the achievements of Mr. Burbank. That would be turning the accomplishment of years into an hour-glass. He has done well in the past. $\mathrm{He}$ is doing better now than at any former period of his interesting career, and under the expanded opportunities now open to him will do his best work hereafter. We may indulge sentiments of gratitude for the past, joy for the present and hopeful prophecy for the future. We offer to him the helpfulness of encouragement and the happiness of appreciation.

Wherever in the civilized world horticulture is practiced the contributions of Luther Burbank to the improvement of familiar species and to the origination of new species, are known. In the most distant lands his name is familiar. We do him honor to-night not only on behalf of California where his work should be best known and his personal worth most highly appreciated, but we greet him in the name of the thousands throughout the civilized world who would be glad to join with us in honoring him. We have not awaited the coming of the sad task of writing epitaphs and composing testimonials to his life services and his personal worth, but are tendering to him the commendation of "well done" while his heart beats in responsive gratitude to this welldeserved commendation and our happiness may be intensified by the pleasure we are conferring.

And now, gentlemen, it is my pleasant duty, on behalf of this company, to propose the health and success of our distinguished fellow citizen, Luther Burbank.

And may we drink this toast standing?

$$
\text { . } 7 \text {. }
$$




\section{Complimentary Banquet to Luther Burbank}

\section{Response, Luther Burbank.}

"Mr. President and my highly esteemed but deluded friends-deluded if you expect Luther Burbank to exhibit that ready facility in handling the English language which these gentlemen who have been chosen to address you possess:

"Ever since I came to this curious world I have steadily on all occasions, tried to mind my own business and especially to escape publicity, but alas, here I am once more dragged out into the lime light. If you came here expecting me to help on the fireworks you have my sympathy, but I congratulate you on the good judgment exhibited in your choice of the gentlemen who have spoken and those who are yet to address you. It was a fine bit of humor to place me in the midst of such a galaxy of orators, and it must be very amusing to you, but this part of the performance is no joke to this victim of untoward circumstances.

"I was brought up in a family like most of you and my cyes have always been wide open when something appeared which promised to be useful to myself or others. Among other things flowers and children never escape my notice, but children respond to ten thousand subtle influences which leave $\mathrm{n}$ ) more impression on a plant than they would on a sphinx. You may say, 'well, what do you know about children?' Anything we love, we study, and I have observed that in searching for good teachers you do not choose parents of large families on account of their superior knowledge of children. You generally select those who have no families of their own. do you not? Therefore, as one of the latter class, I claim the privilege of saying a word for the helpless little victims.

"Some time ago I accorded a St. Louis clergyman a five- 


\section{Complimentary Banquet to Luther Burbank}

minute interview, the result of which is that I have been plunged into the arena of child culture, and fantastic words have been put in my mouth which were never uttered, especially in placing environment so far above heredity. They are on the average equal, in fact, life is a fluctuating balance between these two lines of energy. Sometimes one holds the reins, sometimes the other, but both are always in action where there is life.

"On this subject even many alleged scientists seem very much muddled, and how can those who do not make it a special study be expected to have well-defined ideas on it?

"Biologically considered, each human being is only an outside expression of the great tree of human life, and what I shall say to you this evening is in the belief that any subject is better understood when seen from several slightly different points of view.

"The great questions at stake are, Which has the more influence in building the life of a child, heredity or environment? And, Are acquired characters inherited? My own observations prove that all characters that are inherited have once been acquired, and that heredity is only the sum of all these past environments, which if impressed on the heredity long and strong enough in any specific direction will become a part of heredity itself, and this new heredity, already slightly changed by these late environments will have to meet new environments as before, which will by repetition become fixed in the ever new and constantly fluctuating heredity.

"Did you ever think what is the most pliable and the most precious product of all the ages? It is not pigs, mules, books or locomotives, cotton or corn-but children. Children cannot all be treated alike; each has his or her special individuality, which is the most valuable of all endowments.

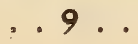




\section{Complimentary Banquet to Luther Burbank}

If all were alike no progress could be made, and right here comes the weakest point in the present educational systems.

"I have long been studying on the intricate complexity of the action of hereditary and environmental forces on life, both in plants and in man and these comparisons and deductions came clearly, sharply and naturally.

"It has been said that to improve a child we should begin with the grandparents. This is only a half-truth, which perhaps had better never have been said. Do not waste any of your time on grandparents unless you commence on them in earliest pliable childhood. If we hope for any improvement of the human race we must begin with the child, as the child responds more readily to environment than any creature in existence. The change may come in the first generation, and it may not. It may not show at all for many generations, but patience and constant attention will finally be rewarded in the survival of the most beautiful, the most precious or the fittest, whichever you may wish to call it.

"You all know that some great force is necessary to change the aspect of minerals and metals. Powerful acids, great heat, electricity, mechanical force or some such influence must be brought to bear upon them. Less potent influences will work a complete change in plant life. Mild heat, sunshine, slight change in atmosphere and greatly diluted chemicals, will all directly affect the growth of the plant and the production of fruits and flowers. And when we come to animal life; especially in man, we find that the force or influence necessary to effect a transformation is cxtremely slight. This is why environment plays such an important part in the development of man.

"In child-rearing environment is equally essential with heredity. Mind you, I do not say that heredity is of no con-

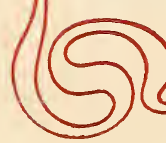




\section{Complimentary Banquet to Luther Burbank}

sequence! It is the great factor, and often makes environment almost powerless. When certain hereditary tendencies are almost indelibly ingrained, environment will have a hard battle to effect a change in the child, but that a change can be wrought by the surroundings we all know. The particular subject may at first be stubborn against these influences, but repeated application to the same modifying forces in succeeding generations will at last accomplish the desired object.

"All animal life is sensitive to environment. You can change the oyster by gradually changing its environment, and you know the oyster is a very low type of life. Take an ox, a horse, a dog, a man, and that which often counts most in the development of each is environment; but of all living things the child is the most sensitive. Surroundings act upon it as the outside world acts upon the plate of the camera: every possible influence acting exteriorily will leave its impress upon the child, and the traits which it inherited will be overcome to a certain extent, in many cases being even more apparent than heredity. The child is like a cut diamond, its many facets receiving sharp, clear impressions not possible to a pebble, with this difference, however, that the changes wrought in the child from the influences without, become constitutional and ingrained. A child absorbs environment. It is the most susceptible thing in the world to influence, and if that force be applied rightly and constantly when the child is in its greatest receptive condition the effect will be pronounced, immediate and permanent.

"There is no doubt that if a child with a vicious temper be placed in an environment of peace and quiet the temper will change. Put a boy born of gentle white parents among Indians and he will grow up like an Indian. Let the child born of criminal parents have a setting of morality and de-

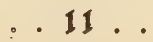




\section{Complimentary Banquet to Luther Burbank}

cency, and the chances are that he will not grow into a criminal but to an upright man. I do not say that heredity will not sometimes assert itself, of course. When the criminal instinct crops out in an individual it might appear as if environment were leveled to the ground, but in succeeding generations the effect of constant higher environmnet will not fail to become fixed.

"We in America form a nation with the bloods of half the peoples of the world within our veins. We are more crossed than any other nation in the history of the world, and here we meet exactly the same results that are always seen in a much crossed race of plants; all the worst as well as all the best qualities of each are brought out in their fullest intensities, and right here is where selective environment counts. All the necessary crossing has been done, and now comes the work of elimination, the work of refining, until we shall get an ultimate product that will be the finest human race which has ever been known. It is perhaps this country which will produce that race. Many years will pass before the finished work is attained, but it is sure to come. The characteristics of the many peoples that make up this nation will show in the composite with many of the evil characteristics removed and the finished product will be the race of the future.

"In my work with plants and flowers I introduce color here, shape there, size or perfume, according to the product desired. In such processes the teachings of nature are always followed. Its great forces only are employed. All that has been done for plants and flowers by crossing, nature has already accomplished for the American people. By the crossings of bloods strength has in one instance been secured, in

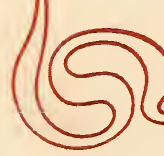




\section{Complimentary Banquet to Luther Burbank}

another intellectuality, in still another moral force. Nature alone could do this. The work of man's head and hand has not yet been summoned to prescribe for the development of a race. A preconceived and mapped-out crossing of bloods has found no place in the making of peoples and nations. But when nature has already done its duty and the crossing leaves a product which in the rough displays the best human attributes, all that is left to be done falls to selective environment.

"Man has by no means reached the ultimate. The fittest has not yet survived. In the process of elimination the weaker must fall, but the battle has changed its base from brute force to mental integrity. We now have what are popularly known as five senses, but there are men of strong minds whose reasoning has rarely been at fault and who are coldly scientific in their methods, who attest to the possibility of yet developing a sixth sense. Who is he that can say man will not develop new senses as evolution advances? Psychology is now studied in the public schools throughout the country, and that study will lead to a greater knowledge of these subjects. The man of the future age will prove a somewhat different order of being from that of the present. He will look upon us as we to-day look upon our ancestors.

"Statistics show many things to make us pause, but after all the proper point of view is that of the optimist. The time will come when insanity will be reduced, suicides and murders will be fewer and man will become a being of fewer mental troubles and bodily ills. Wherever you have a nation in which there is no variation there is comparatively little insanity or crime, or exalted morality or genius. Here in America, where the variation is greatest, statistics show a greater percentage of all these variations. 


\section{Complimentary Banquet to Luther Burbank}

"As time goes on in its endless and ceaseless course, environment will crystallize the American nation. Its varying elements will become unified and the weeding-out process will probably leave the finest human product ever known. The color, the perfume, the size and form that are placed in plants will have their analogies in the composite, the American of the future.

"And now, what will hasten this development most of all? The proper rearing of children. Don't feed children on maudlin sentimentalism or dogmatic religion; give them nature. Let their souls drink in all that is pure and sweet. Rear them, if possible, amid pleasant surroundings. If they come into the world with souls groping in darkness, let them see and feel the light. Don't terrify them in early life with the fear of an after world. There never was a child that was made more noble and good by the fear of a hell. Let nature teach them the lessons of good and proper living. combined with an abundance of well-balanced nourishment. Those children will grow to be the best men and women. Put the best in them by contact with the best outside. They will absorb it as a plant does the sunshine and the dew. In closing, I will give you an appropriate Burbank chestnut and you will all notice that it is a graft. An old lady went to buy a clock. The clerk elaborated on the many excellencies of one of them and ended by saying: 'It will run eight days without winding.' 'Ach! Gott in Himmel! Eight days witout vinding. How long vould it run if it was vound oop?" " 


\section{Complimentary Banquet to Luther Burbank}

\section{Mr. Mills:}

Gentlemen: There is a very marked appropriateness in this testimonial banquet now tendered by the California State Board of Trade. For sixteen years it has been the fixed purpose of this organization to educate the people of California in the enlarged possibilities of the climatic environment of this State. We are far from having exploited the possibilities of the soil and climate of California. Our semi-tropical climate, the fertility of our soils, and the clemency of our seasons, afford opportunity for the introduction here of many objects of culture which would enhance the wealth-producing capacity of our agricultural and horticultural classes, and confer an increased profit upon all field culture.

But the field of exploration has by no means been exhausted. The next toast of the evening is: "The Agricultural and Horticultural Resources of California," and the response has been committed to the very able hands of the Governor of the State, Honorable George C. Pardee.

\section{Response by Governor Pardee.}

Mr. Toastmaster and Gentlemen: The Governor of California has had, and will have, many pleasant duties to perform. But none of them has been and none of them will be quite so pleasant as that which he is this evening called upon to perform, viz: express the high regard in which this evening's honored guest is held by the people of this State.

Working quietly and modestly among his trees and vines, 


\section{Complimentary Banquet to Luther Burbank}

our friend Burbank has worked what, to our lay minds, appear almost like miracles. He has changed the characters and appearances of fruits and flowers, turned pigmies into giants, sweetened the bitter and the sour, transformed noxious weeds into valuable plants, and verily set the seal of his disapproval upon much that to him and us seems wrong in Nature's handiwork. For us he has done much; and to him the whole world is indebted.

We sit here to-night to render tribute to his greatness. Proud to call him "citizen of California," we marvel at the skill with which he has worked his many miracles. And we wonder why we did not know of him before. But genius always struggles against a sea of adversity, and the really great must prove their worth before it is accepted by the world at large. No wonder then that California has been slow to realize that living here within our midst a genius capable of playing tricks with Nature has been cajoling pluns to mate with apricots, turning, better than a lawyer can, the black to white, even disarming the desert cacti of the spines, which wise old Nature, thinking to protect and save them, had placed upon them.

California has much to be proud of, much with which to conjure. Our sun is more genial, our winters and summers more pleasant, our Yosemite deeper, our trees taller, our women handsomer, our men braver, our acres more fertile than those of any other country in the world. Yet I doubt if California has been more widely heralded by any one of these than it has been by the fame of him in whose honor we are met here to-night.

What will he do for us? What has not one of his early products done for all the world? The starving poor of Ireland have had ample cause to bless the genius that produced

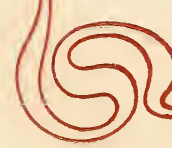

.. 16 . . 


\section{Complimentary Banquet to Luther Burbank}

so lowly, but so important a thing as the potato that bears his name. What will he do for us? The cactus that blooms upon our deserts will, robbed of its spines, perhaps give opportunity for man and beast to populate our almost lifeless wastes. What will he do for us? New fruits, new flowers, new trees seem to spring into being obedient to his Alladin-like touch. Do we want a better plum, a larger berry, a brighter, more fragrant flower, we turn to Burbank, and he gives it to us.

Hitherto the farmer and the horticulturist have groped in almost total darkness, taking now and then some better thing that happened to fall within their grasp, but never fully realizing how that which they prized came into being. Now, like Columbus, Burbank has shown us the way to new continents, new forms of life, new sources of wealth, and we, following in his footsteps, will profit by and from his genius.

Mr. Toastmaster, it is a double pleasure for me to be here to-night. I am glad and proud, as an individual, to honor him whom I may designate as "friend," and I am glad and proud, as Governor of California, and speaking for the million and three quarters of our people, to bid the evening's honored guest a hearty and a heartfelt "Godspeed" in all his future work.

\section{Mr. Mills:}

\section{Gentlemen :}

"Earth gave its chosen men of strength;

They lived, and strove, and died for me;

To stretch my road a nation's length,

And toss the miles aside for me." 


\section{Complimentary Banquet to Luther Burbank}

This is the poetic expression of a very profound philosophy, and the poet Rudyard Kipling sought by this means to enforce the value of citizenship in a great nation.

Our National Government has been ready at all times to respond to this duty of stretching the road of the individual citizen "a nation's length," and making the heights of achievement easily accessible. We are honored by the presence of Honorable George C. Perkins, senior Senator of California, and to him has been assigned the sentiment: "What the Government of the United States has done for Agriculture and Horticulture." It affords me the highest pleasure to introduce our able and distinguished fellow-citizen, Senator George C. Perkins.

\section{Response, Senator Perkins.}

Emerson has said: "If a man can write a better book, preach a better sermon, or make a better mousetrap than his neighbor, though he build his house in the woods, the world will make a beaten path to his door."

The force of this maxim has been truthfully illustrated in the life of our distinguished guest, for scholars and scientists not only from our own country, but from many foreign lands have made the pilgrimage from afar to the Mecca of Santa Rosa to see the cactus and rose bloom without brier or thorn, and to taste delicious fruits whose flavor has been intensified by his wooing.

Only once do I remember of our guest being misrepresented. It was in Philadelphia when I called at a nursery

$$
\text { ..18. . }
$$


Complimentary Banquet to Luther Burbank

to procure some cuttings of the Burbank rose. I asked the salesman who this man Burbank was, that had roses named for him, and who it was said could beat old Ireland in growing potatoes. He replied that Burbank was a Frenchman living in the south of France who accidently discovered the new potato while endeavoring to win a prize offered by a French association to the one who could grow garlic and onions without the offensive odor and not vitiate the flavor of the vegetable. I assure you I took great pleasure in telling that nurseryman that Mr. Burbank was by compulsion a Yankee, born in Massachusetts, but by choice he became a Californian, and his name was the pride of our State.

But I am reminded I should speak to the sentiment proposed: "Our Government Aid to Agriculture" and with your permission I want to say parenthetically that all which relates to the cultivation of the soil has a peculiar interest to me. Perhaps it is because I have even now a vivid recollection when a barefooted New England boy how it hurt to stub my bare toes against the rolling stones in the field when planting corn and beans. Or it may be because later in life I ploughed the ocean, sowing not a few wild oats and harrowing the feelings of those who felt an interest in my welfare. But I am more than grateful that the harvest I have reaped has not all been tares.

As you are aware, the Department of Agriculture was established by an act of Congress May I5, 1862, with a commissioner of agriculture in charge. It did not become an executive department of the government until February 9, I889, when the secretary of agriculture became classed as a cabinet officer. Norman J. Coleman of Missouri, then Commissioner, was commissioned Secretary of Agriculture Feb-

$$
\text { .. } 19 \text {. . }
$$




\section{Complimentary Banquet to Luther Burbank}

ruary I3th, and served to March 6, 1889-twenty-one days -when President Harrison, having been inaugurated, appointed Jeremiah M. Rusk of Wisconsin Secretary of Agriculture. He was succeeded four years later by J. Sterling Morton, of Nebraska, who served during President Cleveland's term.

President McKinley, who was inaugurated March 4, 1897, appointed James Wilson of Iowa, who has served continuously since that time. Secretary Wilson has proved himself to be a most thorough and efficient public official. $\mathrm{He}$ possesses in an eminent degree high executive ability, with a thoroughly practical as well as scientific and technical knowledge of every bureau in the Department of Agriculture.

The appropriation for the support of the Agricultural Department has averaged during the past three years over $\$ 5,000,000$ per annum, and that of the present fiscal year, which commenced July Ist, amounts to $\$ 6,692,690$. This sum seems large, but it has and will continue to return one hundred fold in benefits to the people of our country.

The Secretary of Agriculture places the estimate of the value of the farm for the year 1904-after excluding the value of farm crops fed to live stock-at $\$ 4,900,000,000$; three and one-half times the value of all minerals produced in this country, including coal, iron ore, lead, copper, gold and silver. From year to year the cultivators of the soil have, aside from sustaining eighty millions of people in our own country, contributed food and raw materials for manufacture to millions of people in foreign countries. The farmer's balance of trade has increased from year to year until in 1903 the excess of exports of farm products over the imports amounted to the enormous sum of $\$ 422,000,000$. 


\section{Complimentary Banquet to Luther Burbank}

The Agricultural Department of the government in Washington, through the Bureau of Plant Industry, is co-operating with forty-two State experiment stations along different lines suited to the locality, especially testing new seeds and plants from home and abroad, demonstrating those which are best suited for the soil and climate of any particular locality.

Forty million packets of miscellaneous vegetable and flower seeds are annually distributed on orders from members of Congress. Most excellent results have been obtained in the experiments with, and the distribution of, many of these home-grown seeds in naming the class of soil and climate in which they will thrive the best.

A special appropriation of $\$ 10,000$ was secured last year for the purpose of co-operation with the experiment stations in California for determining the adaptability of various grape stocks to the different soil and climatic conditions of our State. Another appropriation was made for the purpose of investigating diseases affecting plants on the Pacific Coast, particularly with reference to the California vine diseases and diseases of the sugar beet, asparagus, and other vegetables and fruits.

The department sent to California last year 105 varieties of French phyloxera resistant grape vines for trial in infested vineyards.

I do not think it is generally known how large a number of publications is annually issued by the Department of Agriculture. Last year there were issued 972 different publications, and the total number of copies of all publications issued aggregated about $12,421,386$. Of these publications, about seven million were farmer's bulletins, which treat upon almost every subject-matter in which the farmer is interested: agriculture, horticulture, viticulture, forestry, dairy, and

$$
\text { . } 21 \text {. }
$$




\section{Complimentary Banquet to Luther Burbank}

stock-raising. These bulletins, together with the Agricultural Year Book, comprise an encyclopedia of knowledge and information relating to the farm that is invaluable.

There are eight bureaus under the direction of the Department of Agriculture, each having several divisions:

The Weather Bureau.

Bureau of Animal Industry.

Bureau of Plant Industry.

Bureau of Chemistry.

Bureau of Soils.

Bureau of Statistics.

Bureau of Entomology.

Bureau of Forestry.

There are also fifteen divisions of special investigation, such as the botanical, pomological, biological survey, laboratory, etc., with a corps of educated and practical professors in their special lines. A number of them are graduates of the Leland Stanford Jr. University and the University of California, which are respectively presided over by the two distinguished presidents who honor us with their presence here this evening.

These different bureaus in the Agricultural Department are quietly doing their splendid work; and, like smokeless powder, we do not see where the shells come from, but the report is felt on every farm in the country. We feel these benefits in our forest reserves, by the preservation of our forests and the planting of trees on the San Gabriel and other forest reserves in California; we feel them when we learn the adaptability of certain soils to the cultivation of cereals, the improvement of live stock, and their prevention from disease. We feel the beneficial effects in the forecasts of the weather; the warnings given to the farmer of the coming of rain, frost

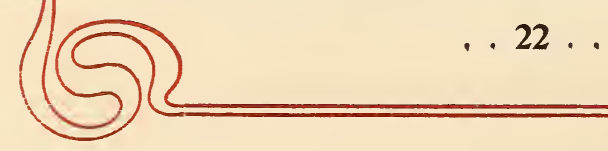


and snow, and to the mariner of the approaching gales of wind. These warnings are given from twenty-four to fortyeight hours in advance on our Atlantic, Gulf and Pacific coasts, and have saved millions of dollars to those engaged in maritime affairs.

Through the encouragement and assistance of this department we now produce nearly all of our sugar beet seed, which formerly was imported from Europe. California produced last year fifty thousand pounds of sugar beet seed. American seed has proven better than the imported; beets testing as high as twenty-four per cent of sugar have been obtained from American beet seed, while the average was fifteen and eight-tenths, and that of foreign-grown seed did not exceed twelve per cent.

Irrigation and instructions in relation to the distribution of water and the amount needed to obtain the best rcsults from different soils, has been derived from actual experience from irrigated districts. There is now in the United States an area of ten million acres of land under irrigation, and over five million more acres tributary to canals in process of construction.

The work of our distinguished guest in his field of agricultural development is an additional incentive to our Government to profit by his experience and discoveries in the evolution of plant life. He is doing more to instruct, interest, and make popular the work in the garden than any man of his generation. California is proud of his achievements and delights to class him as one of her most honored citizens.

The State Board of Trade esteems it a great privilege to extend to him this complimentary banquet, although, knowing his modesty and retiring disposition, we realize that he would rather have remained at his home in the City of Roses,

$$
\text { . } 23 \text {.. }
$$




\title{
Complimentary Banquet to Luther Burbank
}

which has become so dear to him by association with its trees and flowers, for

\author{
"He wanders away and away \\ With Nature, dear old nurse, \\ Who sings to him night and day \\ The rhymes of the universe."
}

\section{Mr. Mills:}

Gentlemen: It was the intention to introduce the next speaker without encomium and without suggestion of subject, but with that profound respect which the absence of these things implies. He has, however, chosen for himself the toast: "The Methods of Luther Burbank and Their Relation to Evolution."

I appreciate keenly the anticipation of pleasure which has filled the minds of this company in listening to the instruction they are now to receive at the hands of Dr. David Starr Jordan, President of the Leland Stanford Junior University. To him, more than to any other citizen of California, except Judge W. W. Morrow, we are indebted for the endowment of the work of Mr. Burbank by "The Carnegie Institution."

\section{Response by President Jordan:}

Dr. Jordan spoke, in substance, as follows:

I am asked by Dr. Wheeler, my colleague in the greater University of California, to express to Mr. Burbank, jointly 


\section{Complimentary Banquet to Luther Burbank}

with my own, the congratulations of both universities. We honor him as a man of our kind, the kind the university delights to make; the kind of men who know things and can do things; the kind of men to whom Nature is an open book, and whose reading of this book is clear and truthful.

I have come farther than any one else to this dinner. When, on the 22d of August, in South Kensington, I received Mr. Briggs' invitation to come here to do honor to Burbank, I packed my trunk at once and sailed for San Francisco. I came the very shortest way, by Londonderry in Ireland to Belle Isle in Labrador. And on the way I heard of this incident:

On the 3oth day of August, on the bleak coast of Labrador, early in the morning, a few strangers came out of their houses, houses they had brought with them on a ship only a few days before, and climbing to the top of a hill, pointed sticks and iron tubes at the sun. The natives said these men were fools. Little by little the sun grew dark, the brown shades stole over the hills, the light shrank to a narrower rim, and then these natives said they were wizards. Other people who knew of the eclipse of the sun and of the expedition sent to Labrador to observe it, said "these are men of science."

Something like this has been Mr. Burbank's experience. Years ago in Massachusetts, he crept around in the mud half a day looking for the lone potato-ball on a plant with which he had been playing. It had been torn off by the foot of a stray cow. People said that he was a fool, not knowing that this one potato-ball was the fruition of years of labor. It was big with the potency of the Burbank potato. Later, when a prosperous nurseryman, he let go all his business to play with scissors and pollen and microscope, planting seeds

.. 25 . . 


\section{Complimentary Banquet to Luther Burbank}

and grafting bushes, then pulling them up and burning them by the thousand, meanwhile growing poorer every year, for the harder he worked the less his financial returns-then people said again he was a fool. Later, when wonderful blooms, gorgeous roses, vigorous walnuts, and flowers and fruits undreamed of, sprang up at Santa Rose, people the world over came to see them and him and said, "Burbank is a wizard."

But when men of science, men like De Vries and his associates, came to see Burbank, they knew him for a man of science. A man of science is one who takes knowledge seriously; who, believing in the truth of human experience, trusts his life to it, and has the courage to use it in his business. All the world knows Burbank now, but there are two who found him out earlier than any one else, and who had faith in his work and his future before any one else had realized what he was doing. These two men are Judge Leib of San Jose and Professor Wickson of the University of California.

I am asked to speak of Burbank's relation to the science of organic evolution, and to the five factors of evolutionheredity, variation, environment, selection and isolation, on the inter-relation of which the movements of life depend.

To understand his relation to these, we must first look at Burbank's method. It is simplicity itself. You can all do the same things in your own gardens. First choose the best of the plants you wish to develop. This is selection, the "magician's wand," as Youatt calls it, by which the breeder can summon up any form of animal or plant he may need for his use or his pleasure. Choose the best; destroy the others; Nature will do the rest. Like produces like; that is heredity. But heredity can be helped along by another ele-

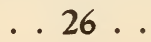




\section{Complimentary Banquet to Luther Burbank}

ment, crossing. Breed the best with the best. Some of the progeny will have the good qualities of both parents, some the bad. If your crosses are wide apart you may get new combinations undreamed of. Select these again. Breed from the best; ruthlessly burn up the rest. A flower is Nature's advertising medium, calling the bees to fertilize her germ cells. There were no showy flowers, flowers with petals, until after there were insects, and to please the insects is the flower's real purpose. You don't want the insects. You must manage the crossing yourself. So snip off the flowers, keep the bees away, and transfer the pollen to the right place with your own dainty fingers. This needs care, skill, patience, science-every virtue demanded by the finestart. And in this art no one has been more skillful than Luther Burbank. Crossing and selection, selection and crossing, this is the whole secret, as simple as any of all the secrets of Nature. It is her method of evolution. Arrange the conditions and Nature will do the rest. But it is one of the finest of all fine arts to arrange these conditions, to bring out the results, results all unseen before, but capable of the exactest forecast.

The commercial value of Burbank's work is great. It can be expressed only in figures far beyond its actual cost. But above all commercial values we must place Burbank's contributions to human knowledge.

Among other things, and I can enumerate but very few, Burbank has shown the plasticity of Nature. Like produces like, but not necessary that which actually is. Children resemble their parents in this way, that they tend to do like things, to develop in like ways under like conditions. Change these conditions and all results are changed. Make conditions better, and new structures and new powers burst out. 


\section{Complimentary Banquet to Luther Burbank}

The mutations of De Vries, in Burbank's view, are the reflex of new conditions.

Burbank has shown us that there is no limit to selection. Once started, variation can be intensified; heredity follows it, and evolution of new forms can be led on and on as far as a continuous purpose may choose to carry it.

Crossing of varieties of one species, and hybridization of distinct species are one and the same thing. Most crosses are fertile, and the results of a skillful cross save years of slow progress by selection. Crossing is to horticulture what punting is to football.

Each group of plants behaves in its own way. Each is a law unto itself. For this reason, as no simple, universal law, like the Mendelian law, can be used to cover every hypothesis, a thousand seedling walnuts, descended from hybrid parents, differ from each other in a thousand ways-in every way conceivable in which walnuts can differ.

The advance of flowers, fruits and grains beyond the primitive types is as great as the advance of palaces as compared with wigwams of steamships as compared with dugout canoes. In Pliny's time, the pear was a little rough fruit, not larger than an olive. In future time, we may go as far beyond the Bartlett pear as that has advanced over the crabpear of the age of Pliny. We are now in the infancy of the work of producing domestic races of animals and plants. No one can forecast the possibilities of the future. And no one will do more than Burbank to make them actual. 


\section{Complimentary Banquet to Luther Burbank}

\section{Mr. Mills:}

Gentlemen:. This banquet was given in part to signalize the good fortune which has lately attended the career of our distinguished guest. The Carneige Institution, founded by an American philanthropist, has endowed the work of $\mathrm{Mr}$. Burbank with one hundred thousand dollars, payable in ten equal annual installments. There is a high sense in which this munificence will redound primarily to the benefit of California. The species which Mr. Burbank will originate will have their first acclimatization here. He will do for this State, aided by the munificence of Mr. Carnegie, what the State should long ago have done for itself.

When the snows of winter fall upon the high summits of the mountains, they are precipitated into the corrugated sides of the lofty summits, and are congealed into glaciers. When the genial sunshine, reinforced by the rains of springtime, fall upon these glaciers, they make no answer back to the sun, but quietly disappear. They are melted into flowing streams, which, passing with torrential velocity down the declivity of the mountains, eventually emerge from the foothills and make their way through the summer-crowned valleys below. Here they summon into life the verdure, the fruits, the flowers and the harvests, and this verdure, these fruits, these flowers and these harvests never reproach the water which calls them into life and being for having once been held in the grip of winter at the frozen summits.

When the enterprise, the commercial instinct, the business capacity and the selfishness, if you will, of man piles up fortunes mountain high, the genial warmth of a philanthropic impulse sometimes thaw's these glaciers and they flow through the channels of nobler achievement, and bring into being

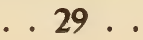




\section{Complimentary Banquet to Luther Burbank}

hospitals for the alleviation of pain, universities for the promotion of learning, institutions for the advancement of science, asylums to shelter the homeless, and religious foundations for the spread of enlightenment. The beneficiaries of all this munificence may well imitate the verdure and the fruits and the flowers and the harvests of the valley by not upbraiding the gold which brings them into life with the reproach that it was once a part of a glacier of wealth at the high summit of financial achievement.

The next toast of the evening is: "The Carnegie Institution, and What It Has Done for California." This toast has been assigned to a director of the Institution, Judge W. W. Morrow of the United States Circuit Court of Appeals. Judge Morrow has been called by official duty to Portland and Seattle, but he has left for your edification a written response to the toast assigned to him. That response will now be read by the Secretary and General Manager of the State Board of Trade, Mr. Arthur R. Briggs.

Response, reading of paper of Judge W.W. Morrow.

Mr. Arthur R. Briggs, General Manager California State Board of Trade, Ferry Building, San Francisco.

My Dear Sir: I regret exceedingly that I cannot be present at the banquet to be given in honor of $\mathrm{Mr}$. Luther Burbank by the California State Board of Trade on the 14th instant. It would afford me great pleasure to join with the Board of Trade and its guests on that occasion in paying a deserved tribute of respect to Mr. Burbank, who has accomplished so much for the benefit of California, and made the

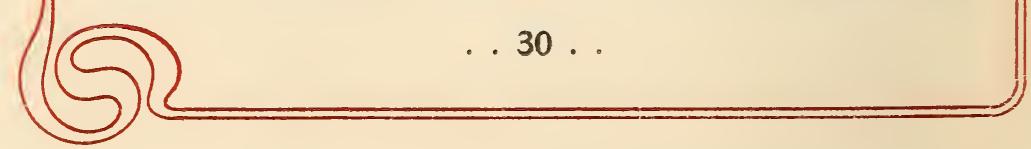




\section{Complimentary Banquet to Luther Burbank}

world better for his having lived in it. But I am compelled to attend sessions of the United States Circuit Court of Appeals during this month at Portland and Seattle, and will not return until about the Ist of October.

The suggestion that I would be called upon, if present, to say something about the Carnegie Institution, offers an agreeable subject for discussion; and while the pleasure of the occasion for me would be to hear others, rather than to speak myself, the suggestion enables me to say in this letter about all that I would say, if present.

Of course I would like to say something in appreciation of the work of my friend Mr. Burbank, whose achievements, I understand, will be the general theme of the occasion. If he is the benefactor of mankind who "makes two ears of corn or two blades of grass to grow upon a spot of ground where only one grew before," what shall we say of Burbank, who makes tons of new varieties of vegetation to grow where none grew before? The satire of Dean Swift upon the insignificance of political service as compared with the value of such a dominion over Nature is a needless disparagement of political services which the country needs and must have, but it does not overestimate the importance of a knowledge of Nature and Nature's laws. Mr. Burbank has done much, and will do more, if he is permitted to carry his plans into execution. But it will be necessary now to give him time, and time to himself, to enable him to follow in plant life the intricate paths of Nature, and interpret to the world her processes of evolution.

Mr. Carnegie believes that man is destined to become an absolute ruler in the kingdom of Nature, and so believing, he founded the Carnegie Institution at Washington, to provide and develop the highest skill and most thorough appli-

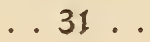




\section{Complimentary Banquet to Luther Burbank}

cation in original research in Nature's laboratory. The Institution was founded on January 28, 1902, with the liberal endowment of ten millions of dollars. After a year of investigation by the savants of this country, and consultation with the learned men of Europe, the principal features of the Institution were declared to be, in the words of Mr. Carnegie, "the promotion of original research as one of the most important of all subjects, and the discovery of the exceptional man, to enable him to make his life work that work for which he seems especially designed." It was in the carrying out of this purpose that the Carnegie Institution came into touch with Mr. Burbank, and proposed to assist him to the fullest extent in his investigations, and to publish and distribute the results of such investigation.

The Trustees of the Carnegie Institution are in a measure under Carlyle's admonition, to let results speak for the Institution, and "forbear to babble of what it is creating and projecting"; and although the Institution has only been in practical working operation for a little over two years, it has already issued over forty important scientific publications, including contributions to nearly all branches of science. It may be interesting to know that a very considerable part of the work of the Institution is being carried on in California at this time. It may be found at our two universities and at the Lick Observatory, solving minor problems in astronomy, bibliography, engineering, mathematics, physics, and zoology. In addition to investigations of this character, some projects of a broader scope are in progress. The bark "Galilee" was recently dispatched from this port by the Carnegie Institution, on the preliminary work of a magnetic survey of the Pacific ocean, which for the present will be directed to that part of the ocean on the west coast and east of a direct line

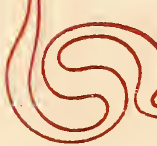




\section{Complimentary Banquet to Luther Burbank}

from the Hawaiian Islands to the Aleutian Islands, and north of a line from the Hawaiian Islands to the mainland. There is also being erected by the Institution a solar observatory on Mount Wilson in Southern California, where the most complete and powerful instruments known will be placed in charge of the most skilled astronomers. The atmospheric conditions on Mount Wilson are exceptionally favorable for solar observations, and it is expected that many interesting discoveries regarding the sun's heat and composition will be made, and the field of astronomical research generally will be greatly extended. In a word, the Carnegie Institution is responding to the urgent demand for deeper and more extensive scientific knowledge, a demand which was vigorously set forth recently in a lecture by Professor Lankester, an English scientist of distinction, at Oxford, England. His contention was that the knowledge and control of Nature is man's destiny and his greatest need, and to accomplish that destiny is the immediate task set before him. He said :

"We desire to make the chief subject of education, both in school and in college, a knowledge of Nature as set forth in the sciences which are spoken of as physics, chemistry, geology and biology. We think that all education should consist in the first place of this kind of knowledge, on account of its commanding importance both to the individual and to the community. We think that every man of even a moderate amount of education should have acquired a sufficient knowledge of these subjects to enable him at any rate to appreciate their value and to take an interest in their progress and application to human life. And we think, further, that the ablest youth of the country should be encouraged to proceed to the extreme limit of present knowledge in one or other branch of this knowledge of Nature, so as to become makers

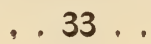




\section{Complimentary Banquet to Luther Burbank}

of new knowledge, and the possible discoverers of enduring improvements in man's control of Nature."

That some part, if not all, of the work of the Carnegie Institution will produce far-reaching results, cannot be questioned. It is equipping an army of investigators for the frontier of human knowledge. There will doubtless be some failures, but the general result will be that man's dominion will be extended; and Burbank, who is an old soldier in this army, will return with much spoil, and additional honors.

Very truly yours,

W. W. MORROW.

\section{Mr. Mills:}

Gentlemen: The original basis of the Commonwealth of California was mining for the precious metals. The agricultural and horticultural value of the State was not even suspected, much less understood. The climatic environment here was unusual. Portions of the State, now the most populous, opulent and prosperous, were relegated to the category of desert.

The "dry season," as we know it now, which is the only winter we know, the occurrence of which covers summer and the early fall months, was regarded as a destructive drought. Its high value to horticulture was not even apprehended. Mining was the paramount industry, a fact clearly disclosed when we read the history of the industries of the State in the light of legislation. To-day, horticulture is the paramount industry, and the art as practiced here is distinctively the result of the experience and thorough investi-
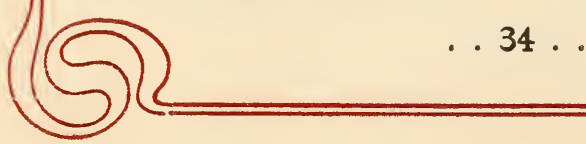


\section{Complimentary Banquet to Luther Burbank}

gation of our own people. The next toast of the evening will be: "What We Know About Horticulture."

Colonel John P. Irish, to whom the response to this toast has been assigned, has been a citizen of the State for more than twenty years. From his earliest residence here he has given the State the benefit of his broad experience, his comprehensive observation and his high intelligence. $\mathrm{He}$ has devoted his very best energies to the development of the material resources of California, and being gifted with the power of statement, his expressions always illuminate any subject which he treats.

In addition to the response which he makes to this toast, as a Director of the California State Board of Trade he will extend the congratulations of the Board to Mr. Burbank.

I felicitate this company on the address he will deliver, and take high pleasure in introducing Colonel John P. Irish.

\section{Response by Colonel John P. Irish.}

The State Board of Trade has for nearly twenty years devoted itself to making known the apparent and latent resources of California. In that time the State has achieved its pre-eminence in horticulture. 'That industry here ranks with the learned professions, requiring study and skill and a close scrutiny of the working of Nature. Man is mighty, but he does not know it all. A small insect, desiring a special fruit for its sustenance, operates upon the limb of an oak tree, and at the point of operation the fruit is produced. Another insect, requiring a different fruit, operates upon the same oak 


\section{Complimentary Banquet to Luther Burbank}

tree and the different fruit grows. These two fruits, and the natural fruit of the tree, grow on the same wood, rooted in the same soil and under the same sunshine. As these fruits, produced by the insects, are not spontaneously produced by Nature, perhaps there are other insects that call these wizards, and declare their method to be secretive and unscientific.

The man who has gone farthest of any into the secrets of Nature, and has controlled and guided her operations to ends most at variance with her spontaneous results, and most valuable to the world, is the guest of the State Board of Trade to-night. Mr. Burbank has conferred upon California the imperishable honor of association with his name and his work. That work has been prosecuted by him with a devotion that admitted no thought of personal gain. The fame of it has gone forth to the world. His life has been so quiet, his absorption so complete, that Californians know him only by his creations whose benefits they enjoy. A gentleman who is here tells me that when in London, entertained hospitably by an English gentleman, his host talked only of Luther Burbank, and the Californian was ashamed to admit that he had never met Mr. Burbank and did not know the location of his wonder-working efforts. When he left he asked his host what he could do to repay his great hospitality, and the Englishman said: "Send me a branch from one of Luther Burbank's plums, from his own nursery, that I may graft it on a stock in my garden, and you will more than repay it all." Another who is a guest here tonight tells me that when in Berlin last year, the intelligent Germans whom he met talked only of two men in the United States-President Roosevelt and Luther Burbank.

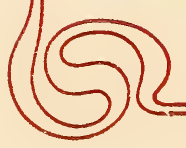




\section{Complimentary Banquet to Luther Burbank}

It is time that Californians knew Mr. Burbank, and the State Board of Trade has made this banquet that they may meet him. It is a pleasure to see hare farmers, actual tillers of the soil, who use the plow and pruning hook, from nine counties in the State, come to meet this student and associate of Nature, who has added wealth to our fields and orchards and beauty to our gardens and bowers, by guiding to perfection and to new forms the fruit of vine and tree and plant, and even the humble weeds of the commons.

\section{Mr. Mills:}

Gentlemen: We now reach the last toast of the evening. The work of Luther Burbank was called to the attention of the Carnegie Institution by a horticultural society of Philadelphia. It will be a matter of regret to this company that the initiative in this important matter was not taken by California. California owes a debt of gratitude to the Philadelphia society which manifested this thoughtfulness.

It must not be assumed from this fact, however, that appreciation on the part of the people of the State for the work and the personal worth of the distinguished guest of the evening is wanting. The toast is one which appeals to State pride and evokes sentiments of State patriotism.

The last toast of the evening is: "Our Neighbor," and is assigned to Albert G. Burnett, Judge of the Superior Court of California for the county of Sonoma, who, as a citizen of Santa Rosa, is a friend and neighbor of our distinguished guest.

I take pleasure in presenting Judge Burnett, who will address you. 


\section{Complimentary Banquet to Luther Burbank}

\section{Response by Judge Burnett.}

My appearance in this presence to respond to the sentiment proposed is rather suggestive of some unenlightened star of the eighth magnitude feebly attempting to shine in the midst of the most splendid galaxy of talent that this State has ever known.

One at all familiar with our public men and orators must commend the judgment of the committee in the selection of the speakers best qualified to do some measure of justice to this occasion in honor of the illustrious guest of the State Board of Trade.

For the entertainment of a veritable king among men, and of those fortunate enough to be permitted to participate at such a feast, what better choice could be made than of the able and affable presiding Justice of the District Court of Appeals; of the learned Rabbi whose eloquence and piety are always manifest, whether addressing an audience of his fellow-men or whether petitioning the throne of Divine Grace; of the versatile toastmaster who knows everything worth knowing and can tell it even better than he knows; of the honored Governor of the State, of whose administration we are all proud, and who has added to his many accomplishments the power of facile and persuasive speech; of our senior United States Senator, who is universally admired and beloved; of the erudite and popular jurist, who presides with such honor and dignity over the United States Circuit Court; of the two eminent presidents of our great universities, and of our gallant naval officer, who is pronounced by competent critics to be one of the few really great orators in the world today. 


\section{Complimentary Banquet to Luther Burbank}

The significance of this reflection is such that were I not a resident of Santa Rosa, the home of Luther Burbank, I could not expect an invitation to address you, nor would I venture the risk of introducing a discordant note into this symphony of beautiful sentiment and apt expression for which we must acknowledge ourselves indebted to these gentlemen, voicing as they do the universal feeling of our people towards the greatest benefactor of this State.

But, prompted by an instinct of courtesy, it is deemed appropriate by the committee to have a representative of his home town to indicate, however feebly, the esteem for the honored guest entertained by his neighbors and fellow citizens, among whom he has lived and toiled for so many years, performing quietly and effectively that work for humanity which shall endure till the end of time.

The inhabitants of our beautiful little city contemplate with pardonable pride the many advantages with which we have been favored by a beneficent Providence.

Our climate is unsurpassed, the soil is wonderfully productive, the people are prosperous and happy. All the conditions of life are favorable for the comfort and welfare of a thrifty, intelligent and industrious citizenship. No more ideal spot could be selected, probably, for the home of such a man as Luther Burbank.

But the many attractions of the place, and of the surrounding country, are for the time forgotten, as distinctive features, when we consider the fact that this wholesome, serious, earnest, kindly, loving, talented and enthusiastic revealer of Nature's most valuable secrets is content to live with us, and thereby associate in the minds of the intelligent people of the world our beautiful little city with the imperishable name of Luther Burbank. 


\section{Complimentary Banquet to Luther Burbank}

In common with you all, we admire Mr. Burbank, as a genius to whom the great of the earth do willing and gracious homage. The wise men, the great philanthropists, the successful and far-seeing students of Nature, they to whom much power has been given to learn of the really valuable things of life, and who are willing to toil and to sacrifice for the world's good, come from the east and from the west, from the north and from the south, to sit at the feet of this great apostle and prophet of beauty and happiness.

They come from the ends of the earth, and count no sacrifice too great, no journey too burdensome, if they may be permitted to see with their own eyes the priceless products of his untiring labors, to learn something of his methods of work, and to catch some measure of his matchless inspiration.

The trackless wastes of the desert, the frozen peaks of the mountains, the innumerable trials of wearisome journeys do not abate the zeal of the pilgrims who gather at the shrine of this High Priest of Nature's secrets.

They remind one of the indomitable resolution and heroic courage of Henry IV of Germany, manifested in his nerveracking journey over the Alps in the dead of winter in that memorable visit to the rocky fastness of Canossa to implore the favor of the mighty Hildebrand.

They come to see this quiet. unassuming citizen, who, if he were to consult his own feelings, would rather emulate Democritus, who rejoiced in the fact that when he came to Athens nobody there did so much as to take notice of him.

We see in Mr. Burbank the "noble ideality" of real, not the "ignoble realty" of spurious greatness. This is revealed to all who know him well. As we consider his work, and as we know the splendid character of the citizen and

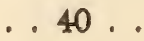




\section{Complimentary Banquet to Luther Burbank}

neighbor, we must feel something of the divine enthusiasm and deep penetration of Emerson when he declared: "Ah, rich and various man! Thou palace of sight and sound, carrying in thy senses the morning and the night and the unfathomable galaxy; in thy brain the geometry of the City of God; in thy heart the power of love and the realms of right and wrong."

The world will always know and do suitable honor to the great achievements of Mr. Burbank. Even now, no other name in the chosen field of his activity stands higher upon the roll of fame.

It is pleasing to reflect that the distinction which has come to him unsought has not disturbed the splendid equipoise of his nature. The current of his life flows on with the same serenity, purity and sweetness that characterized his youth and early manhood.

In the zenith of his power and celebrity, he is still the same modest, earnest, self-sacrificing, toiling and enthusiastic lover of his kind, content to do what he can to brighten and beautify the pathway of life, and to bring more of the sunshine of comfort and happiness into the cottages of the poor as well as the palaces of the rich.

He has done and is doing his work well. He believes with Chapin that "man was sent into the world to be a growing and exhaustless force. The world was spread out around him to be seized and conquered." His is the spirit of all the great army of real men that achieve the welfare of the world. 
LIBRARY OF CONGRESS

|||||||||||||||||||||||||||||||||||||||||||

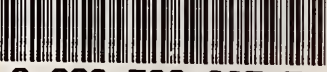

00027602277 
California State Board of Trade Bulletin No. 14

\title{
California State Board of Trade
}

\author{
OFFICES AND EXHIBIT HALL \\ FERRY BUILDING \\ SAN FRANCISCO, CAL.
}

\section{AFICERS}

N. P. Chipman .................... President

J. S. Emery ..................... Vice-President Arthur R. Briggs............. First Vice-President Arthur R. Briggs ........... Secretary and Manager G. A. Dennison ............... Assistant Secretary Wells Fargo Nevada National Bank........ Treasurer

\section{DIRECTORS}
N. P. Chipman
J. S. Emery
W. H. Mills
Geo. C. Perkins
E. W. Maslin
Arthus R. Briggs
J. P. Irish
C. M. Wooster
S. F. Booth
William Haas

H. D. Loveland 


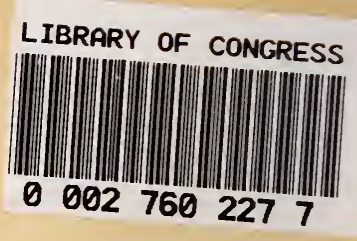

